\title{
Monitoring body condition score of reintroduced banteng (Bos javanicus D'Alton, 1923) into Salakphra Wildlife Sanctuary, Thailand
}

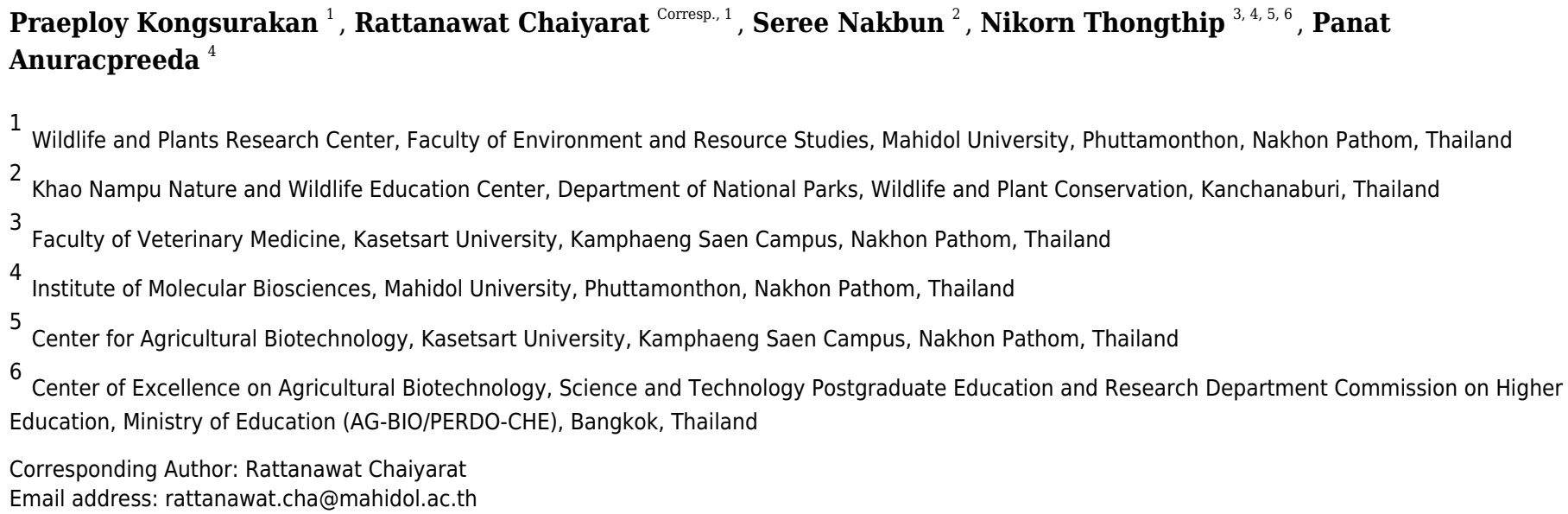

Background. Banteng (Bos javanicus d'Alton 1823) are an endangered species, highly sensitive to habitat structure and quality. In many areas, banteng were extinct and needed to be reintroduced to restore their population. Thus, understanding the responses of body condition of reintroduced banteng to their habitat was important for ensuring the sustainability of a reintroduction program. The aim of the present study was to evaluate the body condition of banteng after reintroduction into the Salakphra Wildlife Sanctuary in Thailand based on photographs from camera-traps carried out between July 2016 and November 2018. Methods. Seven banteng were bred at the Khao Nampu Nature and Wildlife Education Center and systematically reintroduced into the Salakphra Wildlife Sanctuary in December 2015 (four) and July 2016 (three). The seven reintroduced adults and two newborns (from the 2015 group) were captured via camera traps in 2018 . The body condition scoring (BCS) obtained from these photographs was used to identify the individual performance of all seven adults after their reintroduction. Results. The BCS scores in reintroduced adult banteng, both males and females, (between five and seven years old) increased significantly over time after reintroduction into a natural habitat ( $p<$ $0.05)$, although the BCS scores in females were not significantly different between the second and third years $(p>0.05)$. Conclusions. The results from the present study suggest that camera traps are a practical tool to assess the BCS of reintroduced banteng, and can be used to monitor their condition post -release. These techniques may be appropriate for translocation programs elsewhere. 


\section{Monitoring body condition score of reintroduced}

\section{2 banteng (Bos javanicus D Alton, 1923) into Salakphra}

\section{Wildlife Sanctuary, Thailand}

4

5

6

7 Panat Anuracpreeda 4

8 73140, Thailand Pathom, 73170, Thailand

Praeploy Kongsurakan ${ }^{1}$, Rattanawat Chaiyarat ${ }^{1}$, Seree Nakbun², Nikorn Thongthip ${ }^{3,4,5,6}$,

1 Wildlife and Plants Research Center, Faculty of Environment and Resource Studies, Mahidol University, Phuttamonthon, Nakhon Pathom, 73170, Thailand

${ }^{2}$ Khao Nampu Nature and Wildlife Education Center, Department of National Parks, Wildlife and Plant Conservation, Kanchanaburi, 71250, Thailand

${ }^{3}$ Faculty of Veterinary Medicine, Kasetsart University, Kampang Saen, Nakhon Pathom,

${ }^{4}$ Institute of Molecular Biosciences, Mahidol University, Phuttamonthon, Nakhon

${ }^{5}$ Center for Agricultural Biotechnology, Kasetsart University, Kamphaeng Saen Campus, Nakhon Pathom, 73140, Thailand

${ }^{6}$ Center of Excellence on Agricultural Biotechnology, Science and Technology Postgraduate Education and Research Department Commission on Higher Education, Ministry of Education (AG-BIO/PERDO-CHE), Bangkok, Thailand 
23 Corresponding Author:

24 Rattanawat Chaiyarat ${ }^{1}$

25 Wildlife and Plants Research Center, Faculty of Environment and Resource Studies,

26 Mahidol University, Phuttamonthon, Nakhon Pathom, 73170, Thailand

27 Email address: rattanawat.cha@mahidol.ac.th

\section{Abstract}

Background. Banteng (Bos javanicus d'Alton 1823) are an endangered species, highly

sensitive to habitat structure and quality. In many areas, banteng were extinct and

needed to be reintroduced to restore their population. Thus, understanding the responses of body condition of reintroduced banteng to their habitat was important for ensuring the sustainability of a reintroduction program. The aim of the present study was to evaluate the body condition of banteng after reintroduction into the Salakphra Wildlife Sanctuary in Thailand based on photographs from camera-traps carried out between July 2016 and November 2018.

Methods. Seven banteng were bred at the Khao Nampu Nature and Wildlife Education

Center and systematically reintroduced into the Salakphra Wildlife Sanctuary in

December 2015 (four) and July 2016 (three). The seven reintroduced adults and two

41 newborns (from the 2015 group) were captured via camera traps in 2018 . The body condition scoring (BCS) obtained from these photographs was used to identify the

43 individual performance of all seven adults after their reintroduction. 
44 Results. The BCS scores in reintroduced adult banteng, both males and females,

45 (between five and seven years old) increased significantly over time after reintroduction

46 into a natural habitat $(p<0.05)$, although the BCS scores in females were not significantly

47 different between the second and third years $(p>0.05)$.

48 Conclusions. The results from the present study suggest that camera traps are a 49 practical tool to assess the BCS of reintroduced banteng, and can be used to monitor 50 their condition post-release. These techniques may be appropriate for translocation 51 programs elsewhere.

52 Keywords: banteng; body condition score (BCS), camera trap, reintroduction, Salakphra 53 Wildlife Sanctuary

Introduction

Reintroduction is a restoration program in which animals are translocated to areas within their historic range when the population and habitat of the animal there have decreased (Conant, 1988). The role of captive breeding and reintroduction programs that aim to augment or reestablish wildlife populations has increased dramatically

60 (Ebenhard, 1995), including the endangered banteng (Bos javanicus d Alton, 1823), into

61 parts of its former natural range (Armstrong \& Seddon, 2008; Moorhouse et al., 2009;

Massaro et al., 2018).

Banteng of family Bovidae, are distributed in Myanmar, Laos, Vietnam, Cambodia,

64 Borneo (the Malaysian state of Sabah and Indonesian Kalimantan), Java, Bali, and 
65 Thailand (Corbet \& Hill, 1992). Their lifespan is 11 years in the wild and may reach up to

6620 to 25 years in captivity. The basic social group appears to be composed of female-

67 juvenile units (as in other large Asian Bovini) with larger groups tending to be more-or-

68 less temporary assemblages. Maternal herds containing several adult cows, juveniles,

69 and calves occur; these groups can often contain one or more subadult and adult males

70 Groups of cows without calves are also seen. For much of the year, adult banteng are

71 largely sexually segregated and all-male groups are frequently encountered. Solitary

72 animals tend to be mature bulls or sometimes old cows. The composition of small

73 groups of cows with calves or juveniles and the solitary state of old individuals, may

74 remain the same for months or even years. The composition of other small groups,

75 particularly the unisex groups, usually varies from day to day. During the mating season

76 the male groups disband and dominant males compete for access to receptive females

77 (Gardner et al., 2016). The weight of banteng may reach between 600 to $800 \mathrm{~kg}$ in males

78 and 590 to $670 \mathrm{~kg}$ in females. The global population of wild banteng is estimated at

79 between 5,000 and 8,000 (Pudyatmoko, 2004). Banteng prefer more open dry deciduous

80 forests and avoid evergreen rainforests but occupy secondary forest formations that are

81 a result of logging and fires, and enter tracts of sub-humid forest on occasions in the

82 more humid areas of Java and Borneo (Wharton, 1968). However, the predominant

83 habitat type is the tropical lowland dipterocarp forest in Sabah (Gardneret al., 2014).

84 The IUCN has listed banteng as globally endangered (Gardner et al., 2016), but the

85 Convention on International Trade in Endangered Species of Wild Fauna and Flora 
86 (CITES) does not list banteng in its appendix (Gardner et al., 2016) since banteng that

87 are traded in the market are genetically pure and domesticated on farms and classified

88 as a domestic animal. Thus, the trading of this meat is not against CITES law. However,

89 they are protected under the Wildlife Preservation and Protection Act B.E. 2562 (2019) of

90 Thailand (Royal Thai Government Gazette, 2019). Habitat loss and degradation

91 (Srikosamatara, 1993; Prayurasiddhi, 1997) and human disturbances (Gardner, 2014;

92 Gardner et al., 2016; Chaiyarat et al., 2018) have significantly affected banteng and

93 reduced their population, as has commercial hunting (Srikosamatara \& Suteethorn,

94 1995; Chaiyarat et al., 2018) and disease transmitted by domestic cattle (B. taurus and $B$.

95 indicus) that still occur in some protected areas (Chaiyarat \& Srikosamatara, 2009).

96 Accidental hybridization in the wild and active inbreeding between banteng and domestic

97 cattle in captivity to develop the livestock industry reduces the purity of the genetic

98 status of both the wild and captive populations (Purwantara et al., 2012).

99 The wild banteng population in Thailand was decreasing and estimated at only 470 in

100 the 1990s (Srikosamatara, 1993; Srikosamatara \& Suteethorn, 1995). In Salakphra

101 Wildlife Sanctuary, banteng were locally extinct. An example of a successful increase in

102 a banteng population was in the Khao Khiao - Khao Chomphu Wildlife Sanctuary,

103 Chonburi province, Thailand. However, this was an accidental introduction without

104 systematic planning (Chaiyarat et al., 2018). Using lessons learned from this incident, the

105 first systematic introduction of captive-bred banteng into the natural habitat was set up at

106 the Salakphra Wildlife Sanctuary where banteng successfully adapted to the new 
107 environment (Chaiyarat et al., 2019). In 2015, the first group (two males and two females)

108 was reintroduced in December (dry season), while the second group (two males and one

109 female) was reintroduced in July 2016 (wet season) in the same area (Chaiyarat et al.,

1102019 ). The behavior and physiology of banteng can be altered after reintroduction into a

111 new environment, especially by the change of diet and the need to forage. It is important

112 to understand the health status of the population by using a body condition scoring

113 (BCS) system that measures the health of the animals and reflects the status of the

114 program.

115 Body condition scoring systems have been developed and used on many wildlife

116 species to investigate the population integrity when their resources are limited or

117 environment is changing (DelGiudice et al., 2011; Lane et al., 2014; Carpio et al., 2015;

118 McWilliams \& Wilson, 2015). The BCS evaluates the outer appearance of an individual's

119 fitness, including survival and reproduction potential, based on visual cues. The

120 advantages of using the BCS are feasibility, simplicity and low costs (Schiffmann et al.,

121 2017). Thus, measuring animal BCS is important and has been applied to large

122 mammalian herbivores such as African buffalo (Syncerus caffer caffer, Ezenwa et al.,

123 2009), the greater one-horned rhinoceros (Rhinoceros unicorni; Heidegger et al., 2016),

124 Asian elephants (Elephas maximus; Pokharel et al., 2017), and Bornean banteng (Bos

125 javanicus lovii; Prosser et al., 2016).

126 The present study aims to monitor the BCS of these captive-bred banteng in both males

127 and females over three years after reintroduction into a natural habitat by using 
128 photographs from camera-traps. The BCS measurements are a simple and reliable

129 method to score body condition in reintroduced banteng that can be performed by a

130 standardized assessment of photographic views. The BCS can be used to monitor

131 possible animal welfare factors such as body weight development, fertility, and mortality,

132 to improve the overall success rate of reintroductions to promote the conservation of

133 this endangered bovid.

134

135 Materials \& Methods

136 Study area

137 Salakphra Wildlife Sanctuary $\left(14^{\circ} 8^{\prime} 37.09^{\prime \prime} \mathrm{N}, 99^{\circ} 20^{\prime} 33.51\right.$ "E, area: $\left.\sim 860 \mathrm{~km}^{2}\right)$ is located in

138 Mueang, Bo Phloi, Si Sawat and Nong Prue district, Kanchanaburi province, Thailand

139 (Fig. 1). ArcView V.12 (ESRI 2007) and WEFCOM (2004)'s topographic data were used to

140 create the study area map. The altitude of the study site ranges from $700 \mathrm{~m}$ to $1,000 \mathrm{~m}$

141 above averaged sea level (asl). The average rainfall and temperature are 1,071 $\mathrm{mm}$ year

$142{ }^{1}$ and $28^{\circ} \mathrm{C}$, respectively. The vegetation cover is mixed deciduous forest $(60 \%)$, dry

143 dipterocarp forest (30\%), and disturbed areas (10\%). The Lagerstroemia tomentosa,

144 Terminalia alata, T. triptera, T. bellirica, and Afzelia xylocarpa are the dominant cover

145 species in the habitat (Salakphra Wildlife Sanctuary, 2011).

146 This study was accomplished in compliance with the Department of National Parks,

147 Wildlife and Plant Conservation (DNP 0909.204/7103), Thailand. A research ethics 
148 statement was granted by the Mahidol University-Institute Animal Care and Use

149 Committee (MU-IACUC 2018/020)

150

151 Systematic reintroduction of banteng

152 Data were collected as previously described in Chaiyarat et al. (2019, 2020) as follows:

153 1. Training of the banteng before reintroduction

154 During their time in captivity, the banteng underwent general medical checkups and 155 received minimal human contact (Prakobphon, 1988; IUCNISSC, 2013). Seven captive-

156 purebred banteng were bred in a 302 ha enclosure. Four adult males and three adult

157 females between five and seven years old were habituated with transportation boxes (1

$158 \mathrm{~m} \times 2.5 \mathrm{~m} \times 1.8 \mathrm{~m}$, width $\times$ long $\times$ high) individually for of six months at the Khao Nampu

159 Nature and Wildlife Education Center (Chaiyarat et al., 2019). They were then

160 translocated to Salakphra Wildlife Sanctuary where they lived in a soft release cage

161 (Sankar et al., 2013) for four months before release. In the soft release cage, they were

162 kept in groups and their baseline BCS were assessed before being released. The

163 captive-bred banteng had been raised on a diet of Zea mays Linn., Hymenachne

164

pseudointerrupta C. Muell, Hewittia malabarica (L.) Suresh., Trichosanthes cucumerina L.,

165 fresh water and artificial salt licks. While in the training cage, the captive-bred banteng

166 diet was switched to natural plants found in the cage. After reintroduction, natural food

167 plants and salt-licks were the main food sources of the reintroduced banteng. These 
168 main food sources were increased according to the animals' BCS and physiological

169 states (Pokharel et al., 2017).

170

1712 2. Systematic reintroduction of banteng

172 Immobilizations of banteng were controlled with anesthetic drugs: 1) Thiafentanil oxalate

$1730.015 \mathrm{mg} / \mathrm{kg}$ (Thianil TM, Wildlife Pharmaceuticals (Pty) Ltd., South Africa) and 2)

174 Medetomidine HCl 0.015 mg/kg (Kyron Laboratories (Pty) Ltd., South Africa); and reversal

175 drugs: 1) Naltrexone (Thianil TM, Wildlife pharmaceuticals (Pty) Ltd., South Africa) and 2)

176 Atipamizole $\mathrm{HCl}$ (Kyron Laboratories (Pty) Ltd., South Africa), by veterinarians of the

177 National Parks, Wildlife and Plant Conservation and The Zoological Park Organization

178 under the Royal Patronage of His Majesty the King. The animals were fitted with radio

179 collars ( $<3 \%$ of body weight, very high frequency $(\mathrm{VHF})$ transmitters; Advanced

180 Telemetry Systems (ATS), Isanti, MN) using standard capture and marking practices

181 (Powell \& Proulx, 2003) prior to transporting to Salakphra Wildlife Sanctuary. Radio collar

182 signals were tested in the soft release cage before the banteng were reintroduced. First,

183 collar signals were examined one week after reintroduction to reduce the bias when the

184 banteng were not familiar with their new habitat. The radio-collared banteng were

185 monitored periodically every week through ground tracking, using homing in and

186 triangulation techniques (White \& Garrot, 1990) via VHF signals (Chaiyarat et al., 2019).

187 Four individuals of captive-bred banteng were reintroduced in December 2015 during 
188 the dry season (November to April). Shortly, three other individuals were reintroduced in 189 July 2016 during the wet season (May and October).

190

191

192

193

\section{Camera trap survey}

Cameras traps (Bushnell 12 MP Trophy Cam HD Essential Trail Camera, Suresnes, France) were installed between 2016 and 2018 after the second group of banteng were reintroduced. After the camera traps were installed, memory cards and batteries were changed every month in each location for the entire three years. Camera trap locations were selected based on a radio transmitter survey to reduce bias due to trails and other features (Kolowski \& Forrester, 2017). Therefore, water sources within the study site were primarily used as locations for camera trap placement (Varma et al., 2006) followed by natural licks and wildlife trails (Rovero \& Marshall, 2009), which are often visited by banteng and other large mammals (Chaiyarat et al., 2015, 2019) such as wild Asian elephant (Elephas maximus), gaur (Bos gaurus), and sambar deer (Rusa unicolon, etc. Each trap station was installed with two cameras opposite to each other, positioned to photograph both asymmetrical flanks of the banteng for positive identification (Soisalo \& Cavalcanti, 2006). Camera traps were mounted on trees at about $0.75 \mathrm{~m}$ height above ground (Rowcliffe et al., 2008). Camera traps were installed at points ranging between one and three kilometers apart. The camera traps operated continuously, 24 hours per day and the camera shooting interval was one minute. The pictures had a resolution of $1,648 \times 1,236$ pixels. Camera ID, time, date and temperature were also recorded for 
209 each exposure and were stamped on the photographs (Chaiyarat et al., 2019). A total of

2101,879 photographs, out of 191,748 photographs recorded by 12 of 32 camera trap

211 locations (Fig. 2) during 4,602 trap-nights were identified as having captured the banteng

212 (Chaiyarat et al., 2019).

213

\section{Body condition scoring}

215 The morphological characteristics: scars on the body, shape of horns and forehead,

216 labeled collars, and pairing of mother-calf were used for identifying and referring to the

217 specific individuals. Only sufficiently visible images which showed the whole body of the

218 animal were selected for scoring. The visual body condition of banteng was scored by a

219 five-points pictorial scoring system developed from scoring indexes of Bornean banteng

220 (Prosser et al., 2016) and Bali cattle (Soares \& Dryden, 2011). Each individual was given

221 a score in the appearance of seven key areas of its body. Following the index criteria

222 (Supplement Table 1 and Fig. 2 ), the neck (male $=17$ photos, female $=18$ photos), dewlap

223 (male $=18$ photos, female $=18$ photos $),$ shoulders $($ male $=18$ photos, female $=17$ photos $)$,

224 vertebrae $($ male $=18$ photos, female $=16$ photos $)$, ribs $($ male $=18$ photos, female $=18$

225 photos), hindquarters $($ male $=18$ photos, female $=17$ photos $)$, and tail head (male $=13$

226 photos, female $=11$ photos $)$ of the seven bantengs body $(n=36$ photos, 18 photos for

227 both males and females) were categorized with prominent skeletal features and soft

228 tissue by the five-points scoring system. The body composition scores for each area

229 were tabulated to create a database for analysis and future surveys. Body condition 
230 score values were tabulated by three interrelated-assessors: graduate students who

231 developed the BSC (Assessor A), a banteng specialist who contributed to the

232 development of the banteng BCS and has worked with banteng for more than 20 years

233 (Assessor B), and a veterinarian with no prior experience in BCS of any species

234 (Assessor C) (Wemmer et al., 2006; Morfeld et al. 2014). After training, the assessors

235 were tested for consistency using a pilot study of captured photographs obtained from

23610 captive banteng which were then reanalyzed as recommended by Pokharel et al.

237 (2017). The level of percentage agreement was $>80 \%$ as an almost perfect agreement

238 before processing as recommended by Landis and Koch (1977) and Morfeld et al. (2014).

239 In camera-traps, lighting effect, moving animals, clarity and many other factors might

240 complicate the visualization of fat depositions, depressions and projections of bones, etc.

241 These were reanalyzed by comparing with the photographs of captive individuals.

242

243 Statistical analysis

244 The camera-traps were used to capture photographs continuously over the course of

245 the study. The Spearman's rank correlation between categorical body composition and

246 BCS of the four male and three female banteng were used to assess changes in their

247 condition (Wayne, 1990) by using the R package (Niedballa et al., 2016). Chi-square was

248 used to compare the BCS of the banteng between categorical factors such as wet and 249 dry seasons. Mann-Whitney-Wilcoxon rank of the BCS categories from the first, second

250 and third year after the reintroduction of the banteng were determined by using SPSS 
251 (Mamm \& Whitney, 1947). The differences between treatments were tested at the $p<$ 2520.05 significance level.

253

\section{Results}

\section{Body condition scoring system}

256 A total of nine banteng composed of three bulls, four cows and two calves were captured 257 by camera traps. Only the seven adult banteng were used to investigate BCS. The capture rates of banteng photos were $30.8 \%$ of all photos in the first year, $77.8 \%$ in the 259 second and $20 \%$ in the third year. In this study, the criteria for BCS were based on the body composition of seven areas. The Spearman's rank correlation between body composition and BCS of both reintroduced male and female banteng were not different, except in neck and dewlap (male and females), neck and shoulder (males and females), neck and vertebrae (females), neck and rib (males and females), neck and hindquarter

264 (females), dewlap and shoulder (males and females), dewlap and vertebrae (males), 265 dewlap and ribs (males and females), dewlap and hindquarter (males and females), dewlap and tail head (females), vertebrae and ribs (females), vertebrae and hindquarter (males), and hindquarter and tail head (females) that were significantly different $(p<0.05$ )

268 (Table 1).

269 The mean BCS for the body regions of reintroduced banteng ranged between first and 270 fifth level (Fig. 3 and Table 2). In the first year after reintroduction, BCS of females were 271 ranked at $2.43 \pm 0.41$, and skeleton features were still recognized. While the BCS of males 
272 increased to $4.35 \pm 0.34$, and all of the skeletal features were covered with soft tissue in 273 the third year (Fig. 3).

274

275 Improvement of body condition scoring after reintroduction

276 Overall, the BCS of the reintroduced banteng were not significantly different $(p>0.05)$

277 between seasons in both males and females, but the BCS of males were higher in the 278 dry season (Table 2 and Fig 2), but it significantly increased over time in an upward 279 trend after they were reintroduced into the natural habitat, especially in the oldest male 280 (PM) (Table S2 and Fig. 3, 4 \& 5). The average BCS of reintroduced banteng in males 281 was higher than females in all time periods (Table 2). In males, the BCS increased 282 dramatically between the first $(\bar{x}=2.98 \pm 0.35)$ and third years $(\bar{x}=4.35 \pm 0.34, p<0.05$, 283 while in females, BCS were slightly steady between the second $(\bar{x}=2.43 \pm 0.41)$ and third 284 years $(\bar{x}=3.21 \pm 0.10, p>0.05$ ). The average BCS of both sexes gradually rose from the 285 first year $(\bar{x}=2.47 \pm 0.64)$ to the second year $(\bar{x}=3.40 \pm 0.53)$ and the third year $(\bar{x}=3.97 \pm 0.64)$, 286 respectively. The Mann-Whitney $U$ tests showed that the BCS of banteng in both sexes were different between the first and second years $(Z=-2.72, U=250, p=0.006, n=30)$ and between the first and third years $(Z=-3.29, U=80, p=0.001, n=29)$ (Table 2 ).

\section{Discussion}

291 In the Salakphra Wildlife Sanctuary, the BCS of banteng increased in both males and 292 females after being reintroduced into a natural habitat by using camera-traps. The BCS 
293 were not significantly different between wet and dry seasons. The average BCS of male

294 banteng increased in the dry season and decreased in the wet season because the 295 resource quantity and quality in the wet season were higher than in dry season and the 296 early wet season. As the small sample size and individual differenced in BCS changed 297 over the study period, they may influence the results.

298 Monitoring of BCS by using camera-trap is non-invasive to the animals and highly 299 effective in the field due to the low cost and time consumption. The camera-traps can be 300 installed over large areas and can take photographs of animals continuously for long 301 periods of times. As the method is a subjective assessment based on visual appraisal 302 and comparison, there is bound to be variation caused by lighting, posture and 303 observer. However, the error was found to be comparatively small (Fernando et al., 2009). The visual features of each body compositions captured by camera trap can be used to investigate the development of BCS in banteng. The BCS assessment was 306 previously recommended for use to investigate Bornean banteng (Bos javanicus lowi) in

307 logging forests in Sabah, Malaysia (Prosser et al., 2016).

308 The BCS system itself is a robust measure. The results indicated that most of the key 309 areas assessed were strongly correlated, which suggests that the scoring scheme could 310 be simplified without losing much information (Zielke et al., 2017). This study found that 311 dewlaps, ribs and hindquarters gave significantly different results from other body key 312 areas. Nonetheless, more data points of the reference are still preferred. The potential of 313 the reference features should be maximized when a short series of photographs are 
314 scored (Prosser et al., 2016). Meanwhile, the quality of the photographs including

315 brightness and animals' posture might result in differential scoring of each structure.

316 Skeletal features are clearly visible when an animal is stretched out mid-stride but less

317 visible when its posture is relaxed which affects the perceived body condition (Wemmer

318 et al., 2006).

319 The correlations among the scoring of key body areas were assumed to be not

320 significantly different. In this case, all of the seven key areas of the banteng's body

321 significantly correlated to at least two other areas. These findings call attention to the

322 significance of monitoring banteng BCS, and also offers the possibility for estimating

323 parameters in relation to the various body compositions scoring when some key area is

324 missing (Zielke et al., 2017). Nevertheless, validation and calibration of the BCS scoring

325 are still required to decrease the bias of an estimator by assigning the BCS on the

326 training cage and captured photographs, which was then reanalyzed by the observer

327 and other assessors (Pokharel et al., 2017).

328 After reintroduction, the BCS in all individuals increased in the first year. The higher

329 trend of BCS development in bulls may have been affected by their biological traits. High

330 levels of testosterone in males can influence their anatomical and behavioral features,

331 for instance, the large body size, rapidly bulking up, and expressing more aggression,

332 especially during the mating period (Hinch et al., 1984). Males tend to develop their body

333 condition more than females, especially during reproductive periods to compete with

334 other males, for reproductive benefit more than females. On the other hand, the steady 
335 improvement of the females' body condition improvement may be the effect by

336 parturition and lactation during their maturity period similar to dairy cows (López-Gatius

337 et al., 2002) and elephants (Pokharel et al., 2017, 2020) as two calves were found in the

338 third year.

339 The fluctuations of BCS can reflect the quality and quantity of resources and other

340 factors such as parasites or even mortality (Dube, 2005). In order to develop the

341 efficiency of banteng body condition visual scoring in monitoring the reintroduction

342 program, broader details about growth factors, such as age, genetic traits, and

343 nutritional status of captive-bred banteng before and after reintroduction should be

344 implemented in different situations of habitat type, seasonality and stress levels, by

345 comparing across gradients of fragmentation and anthropogenic disturbances as

346 recommended by Pokharel et al. (2017). This could contribute to planning for the welfare,

347 conservation and management of reintroduced banteng populations.

348

349 Conclusions

350 This study has presented a practical technique to evaluate the BCS of reintroduced

351 banteng. The indirect observation of banteng by using the photos from camera traps can

352 be applied. The monitoring allows us to stay connected to the animals responsibly to

353 implement future program management, either by taking active plans or verifying the

354 program's effectiveness. Although a large number of recaptured photographs of animals

355 and a series of individual profiles are required, the integration of visual body condition

356 scoring with photographs of camera trapping is a good option for monitoring the 
357 establishment of a small population. This finding also reveals the positive trend of the

358 banteng reintroduction program as a conservation management tool by humans.

359 Continued monitoring and validation are required for this program implementation to act

360 as a future guideline for other reintroduction programs. The BCS systems should be

361 considered for monitoring reintroduced banteng in other areas, and further evaluations

362 are recommended, including correlations of BCS with body lipid content, subcutaneous

363 fat, weights, shoulder heights, and any other fitness-related traits.

364

365

\section{Acknowledgements}

366

We thank the Salakphra Wildlife Sanctuary and Khao Nampu Nature and Wildlife

367

Education Center, Department of National Parks, Wildlife and Plant Conservation and 368 the Zoological Park Organization Thailand for providing permission and assistance for data collection. Our appreciation and thanks to Dr. Thomas N. Stewart (U.S.A.), Mahidol University, Thailand, for editing the manuscript. This reintroduction program received

371 funding support from the Red Bull Beverage Co., Ltd, Thailand.

372

373

\section{References}

374 Armstrong, D.P. \& Seddon, P.J. (2008). Directions in reintroduction biology. Trends Ecol.

375 Evol. 23, 20-25.

376 Carpio, A.J., Guerrero-Casado, J., Ruiz-Aizpurua L., Tortosa, F.S. \& Vicente, J. (2015).

377 Interpreting faecal nitrogen as a non-invasive indicator of diet quality and body condition

378 in contexts of high ungulate density. Eur. J. Wildl. Res. 61, 557-562. 
379 Chaiyarat, R. \& Srikosamatara, S. (2009). Populations of domesticated cattle and buffalo 380 in the Western Forest Complex of Thailand and their possible impacts on the wildlife 381 community. J. Environ. Manage. 90(3), 1448-1453.

382 Chaiyarat, R., Saengpong, S., Tunwattana, W. \& Dunriddach, P. (2018). Habitat and food 383 utilization by banteng (Bos javanicus d'Alton, 1823) accidentally introduced into the Khao 384 Khieo-Khao Chomphu Wildlife Sanctuary, Thailand. Mammalia 82(1), 23-34.

385 Chaiyarat, R., Youngpoy, N., Kongsurakan, P. \& Nakboon, S. (2019). Habitat preferences 386 of reintroduced banteng (Bos javanicus d'Alton 1823) into the Salakphra Wildlife 387 Sanctuary, Thailand. Wildl. Res. (7)46, 573-.586

388 Chaiyarat, R., Youngpoy, N. \& Prempree, P. (2015). Wild Asian elephant Elephas 389 maximus population in Salakpra Wildlife Sanctuary, Thailand. Endanger. Species Res. $390 \quad 29,95-102$.

391 Conant, S. (1988). Saving endangered species by translocation. BioSci. 38, 254-257.

392 Corbett, G.B. \& Hill, J.E. (1992). The Mammals of the Indomalay Region: A Systematic 393 Review. Natural History Museum Publications. Oxford: Oxford University Press.

394 Corder, G.W. \& Foreman, D.I. (2014). Nonparametric Statistics: A Step-by-Step Approach. 395 Hoboken, NJ: Wiley.

396 DelGiudice, G.D., Sampson, B.A., Lenarz, M.S., Schrage, M.W. \& Edwards, A.J. (2011).

397 Winter body condition of moose (Alces alces) in a declining population in Northeastern 398 Minnesota. J. Wildl. Dis. 47, 30-40. 
399 Dobson, A.P., Rodriguez, J.P., Roberts, W.M. \& Wilcove, D.S. (1997). Hopes for the future:

400 Restoration ecology and conservation biology. Sci. 277, 515-522.

401 Dube, S. (2005). A Model for Adaptive Livestock Management on Semi-Arid Rangelands

402 in Texas. Texas: Ph.D. Thesis, Texas A\&M University.

403 Ebenhard, T. (1995). Conservation breeding as a tool for saving animal species from

404 extinction. Trends Ecol. Evol. 10, 438-443.

405 ESRI. (2007). ESRI® Data \& Maps 2006. NY: ESRI: www,esri.comindex.html.

406 Ezenwa, V.O., Jolles, A.E. \& O’Brien, M.P. (2009). A reliable body condition scoring

407 technique for estimating condition in African buffalo. Afr. J. Ecol. 47, 476-481.

408 Fernando, P., Janaka, H.K., Ekanayaka, S.K.K., Nishantha, H.G., \& Pastorini, J. (2009). A

409 simple method for assessing elephant body condition. Gajah 31, 29-31.

410 Gardner, P.C. (2014). The natural history, Non-invasive Sampling, Activity Patterns and

411 Population Genetic Structure of the Bornean Banteng Bos javanicus lowi in Sabah,

412 Malaysian Borneo. Ph.D. Thesis, Cardiff University.

413 Gardner, P.C., Hedges, S., Pudyatmoko, S., Gray, T.N.E. \& Timmins. R. (2016). Bos

414 javanicus. The IUCN Red List of Threatened Species. e.T2888A46362970.

415 http://dx.doi.org/10.2305/UCN.UK.2016-2.RLTS.T2888A46362970.en. Accesses 24 July

4162018.

417 Gardner, P.C., Pudyatmoko, S., Bhumpakphan, N., Yindee, M., Ambu, D.L.N. \&

418 Goossens, B. (2014). Banteng Bos javanicus. In Ecology, Evolution and Behaviour of Wild 
419 Cattle: Implications for Conservation. Melletti, M. and Burton J. (Ed.). Cambridge:

420 Cambridge University Press.

421 Heidegger, E.M., von Houwald, F., Steck, B. \& Clauss, M. (2016). Body condition scoring

422 system for greater one-horned rhino (Rhinoceros unicornis): Development and

423 application. Zoo Biol. 35(5), 432-443.

424 Hinch, G.N. \& Thwaites, C.J. (1984). The growth rates of bulls and steers under grazing

425 conditions in different seasons and years. Aust. Soc. Anim. Prod. 15(1), 392-394.

426 IUCN/SSC. (2013). Guidelines for Reintroductions and Other Conservation

427 Translocations. Version 1.0. Gland, Switzerland: IUCN Species Survival Commission.

428 Kolowski, J.M. \& Forrester, T.D. (2017). Camera trap placement and the potential for bias

429 due to trails and other features. PLOS ONE 12(10), e0186679.

430 Landis, J.R. \& Koch, G.G. (1977). The measurement of observer agreement for

431 categorical data. Biometrics 33(1), 159-74.

432 Lane, E.P., Clauss, M., Kock, N.D., Graham, H.F.W., Majok, A.A., Kotze, A. \& Codron, D.

433 (2014). Body condition and ruminal morphology responses of free ranging impala

434 (Aepyceros melampus) to changes in diet. Eur. J. Wildl. Res. 60, 599612.

435 Lekagul, B. \& McNeely, J.A. (1977). Mammals of Thailand. Bangkok: Association for the 436 Conservation of Wildlife. 
437 López-Gatius, F., Yániz, J. \& Madriles-Helm, D. (2003). Effects of body condition score 438 and score change on the reproductive performance of dairy cows: a meta-analysis.

439 Theriogenol. 59(3-4), 801-812.

440 Mann, H.B. Whitney, D.R. (1947). On a test of whether one of two random variables is

441 stochastically larger than the other. Ann. Math. Statist. 18(1), 50-60.

442 Massaro, M., Chick, A., Kennedy, E.S. \& Whitsed, R. (2018). Post-reintroduction

443 distribution and habitat preferences of a spatially limited island bird species. Anim.

444 Conserv. 21, 54-64.

445 McWilliams, M. \& Wilson, J.A. (2015). Home range, body condition, and survival of 446 rehabilitated raccoons (Procyon loton during their first winter. J. Appl. Anim. Welfare Sci.

447 18, 133-152.

448 Moorhouse, T., Gelling, M. \& Macdonald, D. (2009). Effects of habitat quality upon 449 reintroduction success in water voles: Evidence from a replicated experiment. Biol. 450 Conserv. 142, 53-60.

451 Morfeld, K.A., Meehan, C.L., Hogan, J.N. \& Brown, J.L. (2016). Assessment of body 452 bondition in African (Loxodonta africana) and Asian (Elephas maximus) elephants in 453 North American zoos and management practices associated with high body condition 454 scores. PLOS ONE 11, e0155146.

455 Niedballa, J., Sollmann, R., Courtiol, A. \& Wilting, A. (2016). camtrapR: an R package for 456 efficient camera trap data management. Methods Ecol. Evol. 7, 1457-1462. 
457 Pokharel, S.S., Seshagiri, P.B. \& Sukumar, R. (2017). Assessment of season-dependent

458 body condition scores in relation to faecal glucocorticoid metabolites in free-ranging

459 Asian elephants. Conserv. Physiol. 5, doi:10.1093/conphys/cox039.

460 Pokharel, S.S., Seshagiri, P.B. \& Sukumar, R. (2020). Influence of the number of calves

461 and lactating adult females in a herd on the adrenocortical activity of free-ranging Asian

462 elephants. Wildl. Res. 46(8), 679-689.

463 Powell, R.A. \& Proulx, G. (2003). Trapping and marking terrestrial mammals for research:

464 Integrating ethics, performance criteria, techniques, and common sense. Inst. Lab. Anim.

465 Res. J.4(4), 259-276.

466 Prakobphon, N. (1988). Behaviour of banteng (Bos javanicus) in Chiang Mai Zoo

467 Changwat Chiang Mai and Khao Kheow Open Zoo Changwat Chonburi. Mater Thesis,

468 Chiang Mai University.

469 Prayurasiddhi, T. (1997). The ecological separation of gaur (Bos gaurus) and banteng

470 (Bos javanicus) in Huai Kha Khaeng Wildlife Sanctuary. Dissertation, University of

471 Minnesota.

472 Prosser, N S., Gardner, P.C., Smith, J.A., Goon Ee Wern, J., Ambu, L.N., \& Goossens, B.

473 (2016). Body condition scoring of Bornean banteng in logged forests. BMC Zool. 1(1), 1-8.

474 Pudyatmoko, S. (2004). Does the banteng (Bos javanicus) have a future in Java?

475 Challenges of the conservation of a large herbivore in a densely populated island, The

476 3rd IUCN World Conservation Congress. Bangkok: IUCN. 
477 Purwantara, B., Noor, R.R., Andersson, G. \& Rodriguez-Martinez, H. (2012). Banteng and 478 Bali cattle in Indonesia: Status and forecasts. Reprod. Domest. Anim. 47(Supplement 1), 2 4796.

480 Rovero, F. \& Marshall, A.R. (2009). Camera trapping photographic rate as an index of 481 density in forest ungulates. J. Appl. Ecol. 46, 1011-1017.

482 Rowcliffe, J.M., Field, J., Turvey, S.T. \& Carbone, C. (2008). Estimating animal density 483 using camera traps without the need for individual recognition. J. Appl. Ecol. 45, 12284841236.

485 Royal Thai Government Gazette. 2019. Wildlife Preservation and Protection Act, 486 B.E.2562 (2019) of Thailand. www.ratchakitcha.soc.go.th. Downloaded on 1 December 487 2019. (In Thai)

488 Salakphra Wildlife Sanctuary. (2011). Master plan of Salakphra Wildlife Sanctuary BC 489 2554-2558, Kanchanaburi Province. Kanchanaburi: Areas Regional Office 3 (Ban Pong), 490 Department of National Park.

491 Sankar, K., Pabla, H.S., Patil, C.K., Nigam, P., Qureshi, Q., Navaneethan, B., Manjrekar, 492 M., Virkar, P.S. \& Mondal, K. (2013). Home range, habitat use and food habits of re493 introduced gaur (Bos gaurus gaurus) in Bandhavgarh Tiger Reserve, Central India. Trop. 494 Conserv. Sci. 6(1), 50-69. 
495 Schiffmann, C., Clauss, M., Hoby, S. \& Hatt, J.-M. (2017). Visual body condition scoring in 496 zoo animals-composite, algorithm and overview approaches. J. Zoo and Aquar. Res. 5(1), $497 \quad 1-10$.

498 Seddon, P.J. (1999). Persistence without intervention: assessing success in wildlife 499 reintroductions. Trends Ecol. Evol. 14, 503.

500 Shugart, H.H., French, N.H.F., Kasischke, E.S., Slawski, J.J., Dull, C.W., Shuchman, R.A. 501 \& Mwangi, J. (2001) Detection of vegetation change using reconnaissance imagery. 502 Global Change Biol. 7, 247-252.

503 Soares, F. \& Dryden, G.M. (2011). A body condition scoring system for Bali cattle. Asian504 Australas J. Anim. Sci. 24(11), 1587-1594.

505 Soisalo, M.K. \& Cavalcanti, S.M.C. (2006). Estimating the density of a jaguar population in 506 the Brazilian Pantanal using camera-traps and capture-recapture sampling in 507 combination with GPS radio-telemetry. Biol. Conserv. 129, 487-496.

508 Srikosamatara, S. (1993). Density and biomass of large herbivores and other mammals 509 in a dry-tropical forest, western Thailand. J. Trop. Ecol. 9, 33-43.

510 Srikosamatara, S. \& Suteethorn, V. (1995). Populations of gaur and banteng and their 511 management in Thailand. Nat. His. Bull. Siam Soc. 43, 55-83.

512 Sutherland, W.J., Armstrong, D., Butchart, S.H., Earnhardt, J.M., Ewen, J., Jamieson, I., 513 Jones, C.G., Lee, R., Newbery, P. \& Nichols, J.D. (2010). Standards for documenting and 514 monitoring bird reintroduction projects. Conserv. Let. 3, 229-235. 
515 Varma, S., Pittet, A. \& Jamadagni, H.S. (2006). Experimenting usage of camera-traps for 516 population dynamics study of the Asian elephant Elephas maximus in southern India.

517 Curr. Sci. 91, 324-331.

518 Wayne, W.D. (1990). Spearman Rank Correlation Coefficient. In Applied Nonparametric

519 Statistics: pp. 358-365. 2nd edn. Boston: PWS-Kent.

520 WEFCOM (Western Forest Complex). (2004). GIS Database and Its Applications for

521 Ecosystem Management. Department of National Park, Wildlife, and Plant Conservation,

522 Bangkok.

523 Wemmer, C., Krishnamurthy, V., Shrestha, S., Hayek, L.A., Thant, M. \& Nanjappa, K.

524 (2006). Assessment of body condition in Asian elephants (Elephas maximus). Zoo Biol. $525 \quad 25(3), 187-200$.

526 Wharton, C.H. (1968). Man, fire and wild cattle in Southeast Asia. Tall Timbers Fire Ecol.

527 Conf. Proceed. 8, 107-167.

528 White, G.C.\& Garrot, R.A. (1990). Analysis of Radio-Tracking Data. CL: Academic Press.

529 Royal Thai Government Gazette. 2019. Wildlife Preservation and Protection Act B.E.

530 2562. http:/www.ratchakitcha.soc.go.th/DATAPDF//2562A/071T_.0104PDF.

531 Zielke, L., Wrage-Mönnig, N., Müller, J. 2018. Development and assessment of a body

532 condition score scheme for European bison (Bison bonasus). Anim. 8(163), 1-10. 


\section{Figure Legends}

535 Figure 1 Location of banteng (Bos javanicus) presence and camera stations in

536 Salakphra Wildlife Sanctuary.

537 Figure 2 The body composition for body condition scoring (BCS) of banteng (Bos

538 javanicus) (a) and photographic features of banteng in each location of body composition

539 in each BCS criteria (b) in Salakphra Wildlife Sanctuary.

540 Figure 3 The body condition score (BCS) improvement of three males and four females

541 banteng (Bos javanicus) between wet (males $=4$ photos individual $^{-1}$, females $=3$ photos

542 individual $^{-1}$ ) and dry (males $=2$ photos individual $^{-1}$, females $=1$ photo individual ${ }^{-1}$ for 2

543 individuals and 2 photos individual $^{-1}$ for 2 individuals) seasons in Salakphra Wildlife

544 Sanctuary after the reintroduction.

545 Figure 4 The body condition score (BCS) improvement of four females (open dots) and

546 Three males (closed dots) banteng (Bos javanicus) in Salakphra Wildlife Sanctuary in the

547 first $(n=13$ photos of three females and $n=10$ photos of three males), second $(\mathrm{n}=$ three

548 photos of two females and $n=$ four photos of two males) and third year ( $n$ =two photos of

549 one female and $n$ =four photos of two males) after the reintroduction.

550 Figure 5 Rate of increase in body condition score (BCS) of banteng (Bos javanicus) in

551 females compared to males in the Salakphra Wildlife Sanctuary in the first $(n=13$ photos

552 in three females and $n=10$ photos in three males), second ( $n=$ three photos in two 
553 females and $n=$ four photos in two males) and third year ( $n=$ two photos in one females

554 and $n=$ four photos in two males) after the reintroduction.

555 


\section{Table Legends}

557 Supplement Table 1 The scoring criteria for seven body compositions of the banteng 558 (Bos javanicus) in Salakphra Wildlife Sanctuary.

559 Supplement Table 2 The seven body compositions of the banteng (Bos javanicus) in

560 each individual, sex, age, year of reintroduction in Salakphra Wildlife Sanctuary.

561 Table 1Spearman's rank correlation of body key areas' score of the reintroduced

562 banteng (Bos javanicus) in Salakphra Wildlife Sanctuary.

563 Table 2 Body condition score (BCS), chi-square and Mann-Whitney-Wilcoxon rank test of

564 male and female reintroduced banteng (Bos javanicus) between the first and the third 565 year of reintroduction program in Salakphra Wildlife Sanctuary. 
Figure 1

Location of banteng (Bos javanicus) presence and camera stations in Salakphra Wildlife Sanctuary.

Figure 1 Location of banteng (Bos javanicus) presence and camera stations in Salakphra Wildlife Sanctuary.

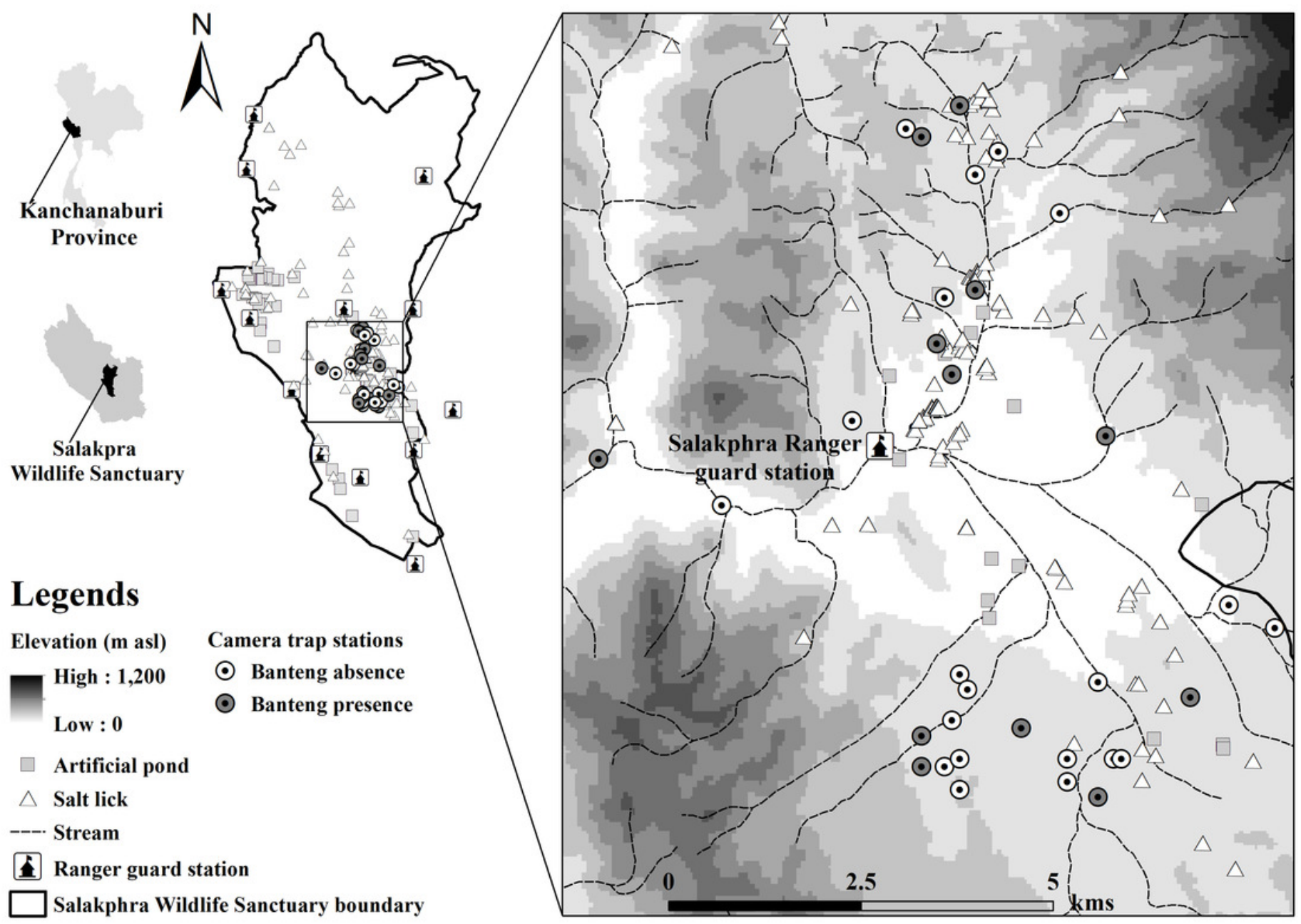




\section{Figure 2}

The body composition for body condition scoring (BCS) of banteng (Bos javanicus) (a) and photographic features of banteng in each location of body composition in each BCS criteria (b) in Salakphra Wildlife Sanctuary.

Figure 2 The body composition for body condition scoring (BCS) of banteng (Bos javanicus) (a) and photographic features of banteng in each location of body composition in each BCS criteria (b) in Salakphra Wildlife Sanctuary. 

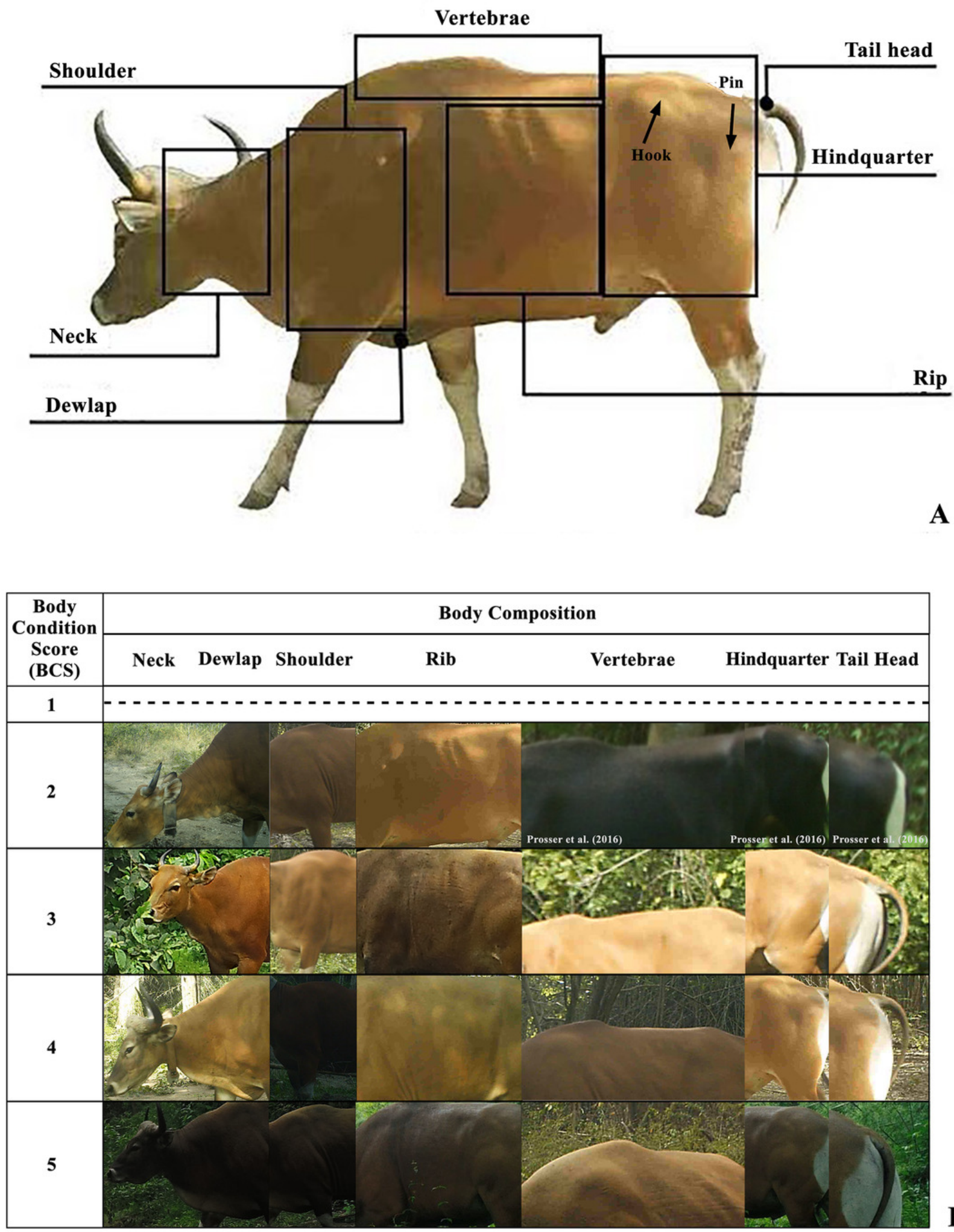


\section{Figure 3}

The body condition score (BCS) improvement of three males and four females banteng (Bos javanicus) between wet (males $=4$ photos individual ${ }^{-1}$, females $=3$ photos individual $^{-1}$ ) and dry (males $=2$ photos individual ${ }^{-1}$, fem

Figure 3 The body condition score (BCS) improvement of three males and four females banteng (Bos javanicus) between wet (males $=4$ photos individual ${ }^{-1}$, females $=3$ photos individual $^{-1}$ ) and dry $\left(\right.$ males $=2$ photos individual ${ }^{-1}$, females $=1$ photo individual ${ }^{-1}$ for 2 individuals and 2 photos individual ${ }^{-1}$ for 2 individuals) seasons in Salakphra Wildlife Sanctuary after the reintroduction.

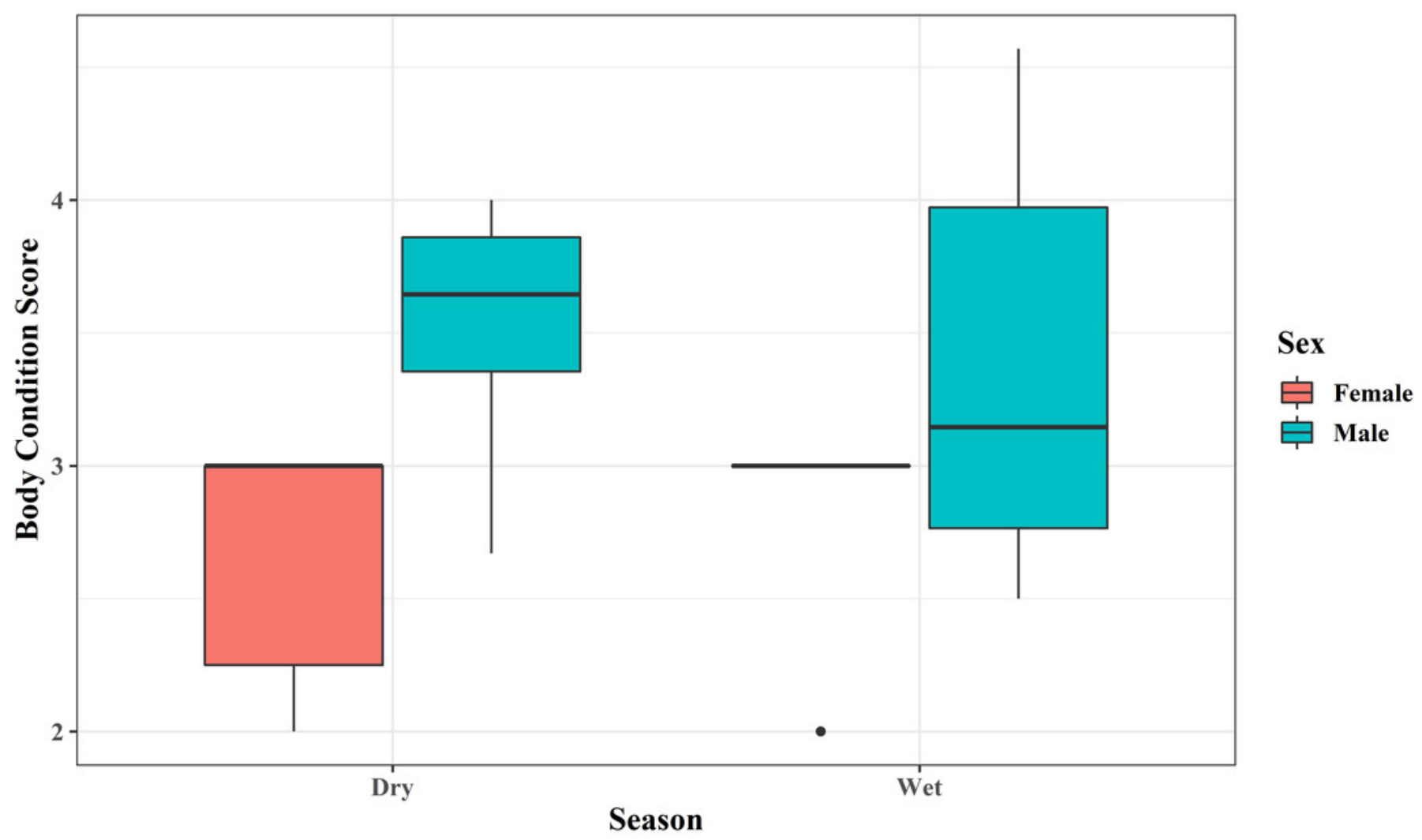


Figure 4

The body condition score (BCS) improvement of four females (open dots) and Three males (closed dots) banteng (Bos javanicus) in Salakphra Wildlife Sanctuary in the first ( $n=13$ photos of three females and $n=10$ photos of three males)

Figure 4 The body condition score (BCS) improvement of four females (open dots) and Three males (closed dots) banteng (Bos javanicus) in Salakphra Wildlife Sanctuary in the first ( $n=$ 13 photos of three females and $n=10$ photos of three males), second ( $n=$ three photos of two females and $n=$ four photos of two males) and third year ( $n=$ two photos of one female and $n=$ four photos of two males) after the reintroduction.

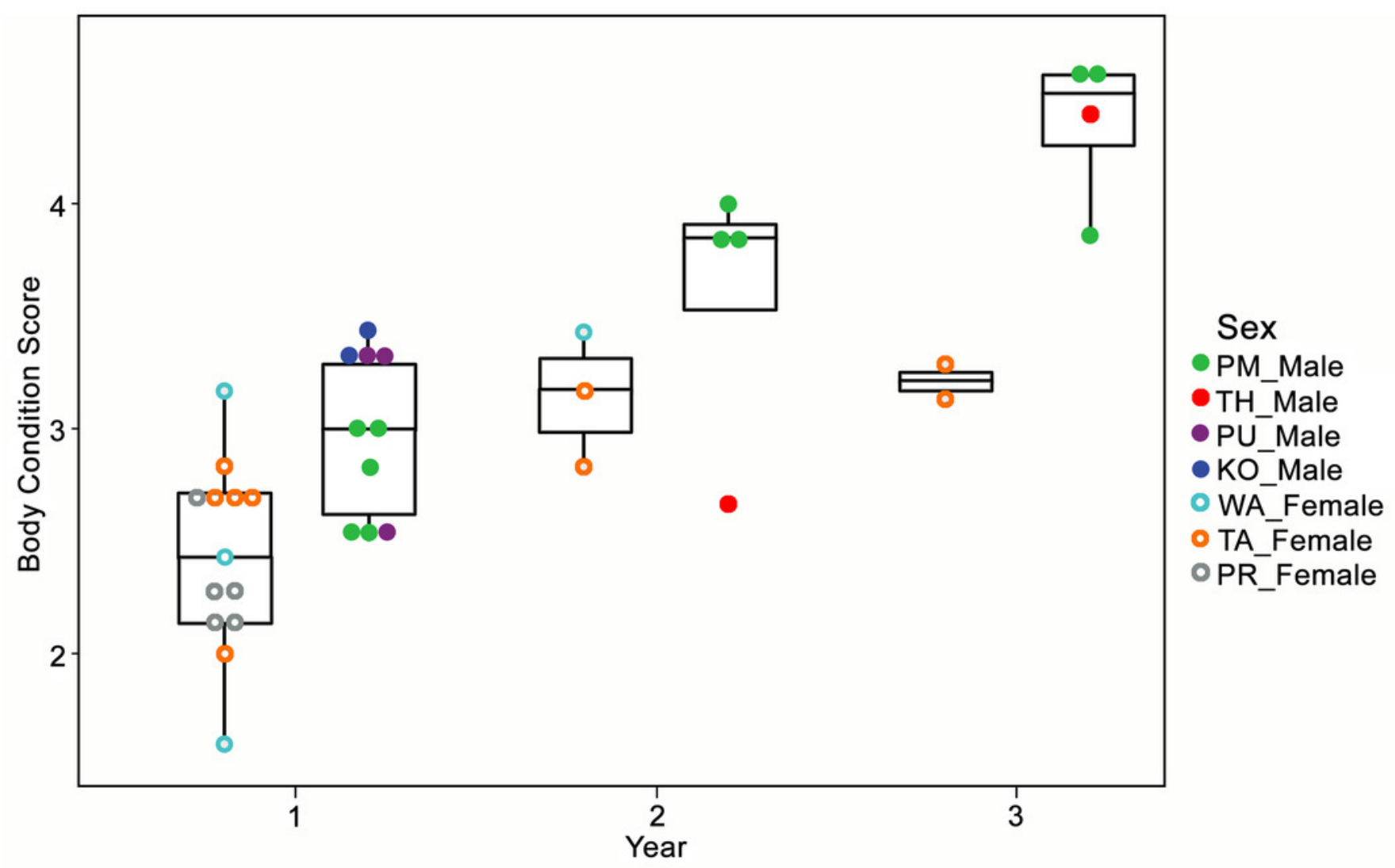




\section{Figure 5}

Rate of increase in body condition score (BCS) of banteng (Bos javanicus) in females compared to males in the Salakphra Wildlife Sanctuary in the first $(n=13$ photos in three females and $n=10$ photos in three males), second ( $n=$

Figure 5 Rate of increase in body condition score (BCS) of banteng (Bos javanicus) in females compared to males in the Salakphra Wildlife Sanctuary in the first $(n=13$ photos in three females and $n=10$ photos in three males), second ( $n=$ three photos in two females and $n=$ four photos in two males) and third year ( $n=$ two photos in one females and $n=$ four photos in two males) after the reintroduction. 


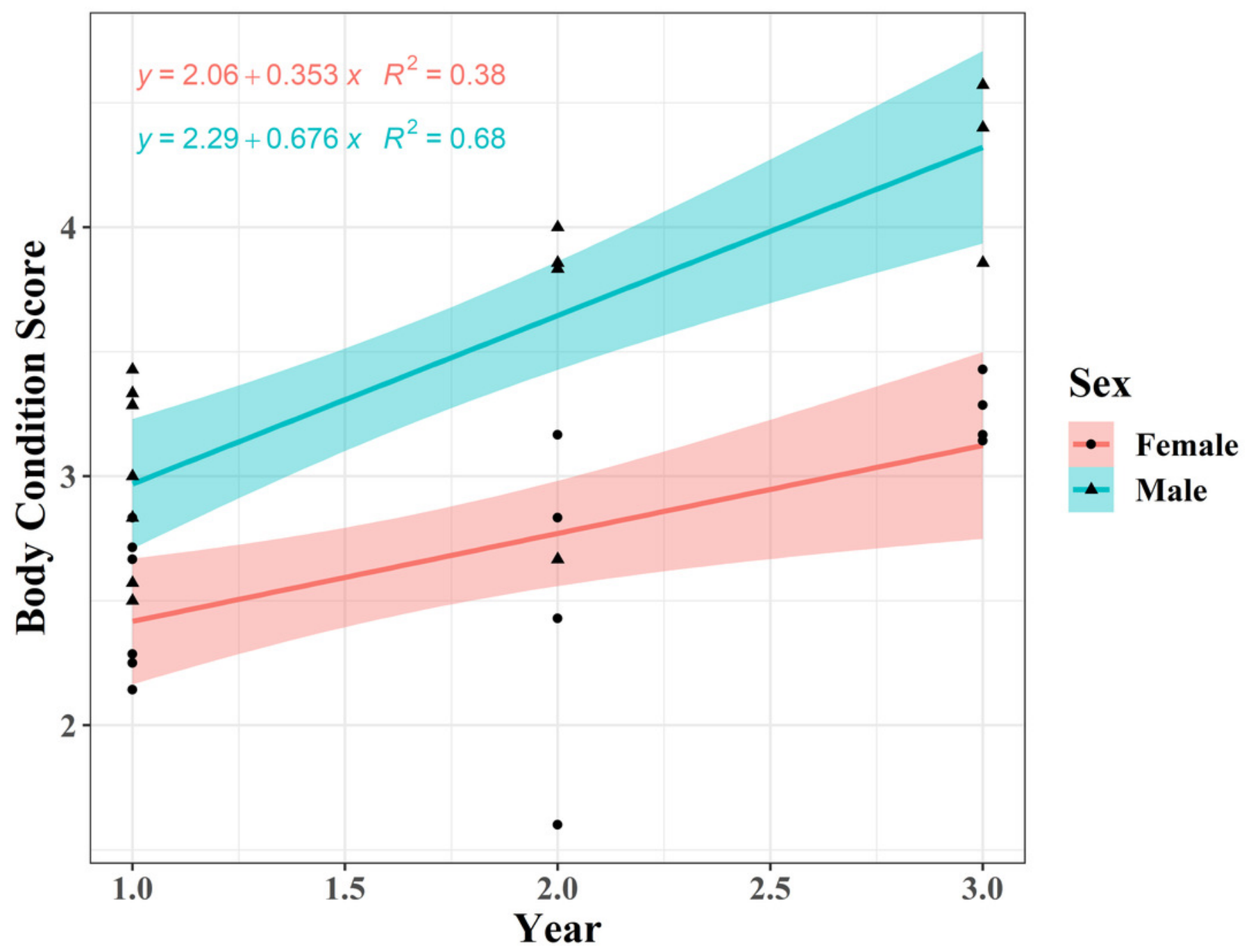




\section{Table $\mathbf{1}$ (on next page)}

Spearman's rank correlation of body key areas' score of the reintroduced banteng (Bos javanicus) in Salakphra Wildlife Sanctuary.

Table 1 Spearman's rank correlation of body key areas' score of the reintroduced banteng (Bos javanicus) in Salakphra Wildlife Sanctuary. 
1 Table 1 Spearman's rank correlation of body key areas' score of the reintroduced

2 banteng (Bos javanicus) in Salakphra Wildlife Sanctuary.

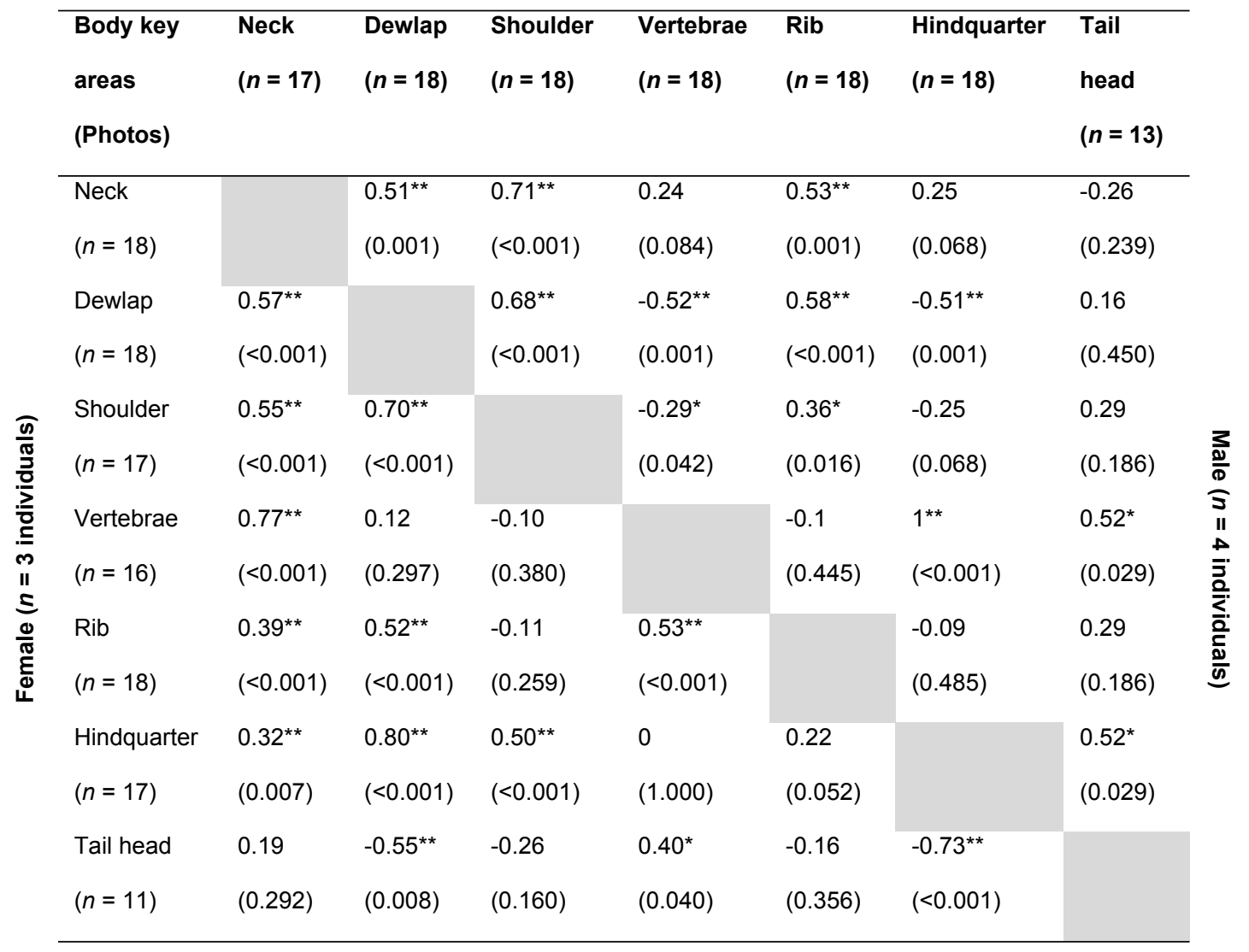

3 


\section{Table 2 (on next page)}

Body condition score (BCS), chi-square and Mann-Whitney-Wilcoxon rank test of male and female reintroduced banteng (Bos javanicus) between the first and the third year of reintroduction program in Salakphra Wildlife Sanctuary.

Table 2 Body condition score (BCS), chi-square and Mann-Whitney-Wilcoxon rank test of male and female reintroduced banteng (Bos javanicus) between the first and the third year of reintroduction program in Salakphra Wildlife Sanctuary. 
1 Table 2 Body condition score (BCS), chi-square and Mann-Whitney-Wilcoxon rank test

2 of male and female reintroduced banteng (Bos javanicus) between the first and the third

3 year of reintroduction program in Salakphra Wildlife Sanctuary.

\begin{tabular}{|c|c|c|c|c|c|c|c|c|c|c|}
\hline \multirow[t]{2}{*}{ Sex } & \multicolumn{10}{|c|}{ Body condition score in season and year after reintroduction } \\
\hline & Wet & $n$ & Dry & $n$ & $1^{\text {st }}$ & $n$ & $2^{\text {nd }}$ & $n$ & $3^{\text {rd }}$ & $n$ \\
\hline Male & $3.37 \pm 0.78$ & 12 & $3.53 \pm 0.50$ & 6 & $2.98 \pm 0.35$ & 77 & $3.59 \pm 0.62$ & 30 & $4.35 \pm 0.34$ & 30 \\
\hline Female & $2.83 \pm 0.39$ & 12 & $2.67 \pm 0.52$ & 6 & $2.43 \pm 0.41$ & 94 & $3.14 \pm 0.30$ & 22 & $3.21 \pm 0.10$ & 16 \\
\hline $\begin{array}{l}\text { Both } \\
\text { sexes }\end{array}$ & $2.95 \pm 0.78$ & 24 & $3.19 \pm 0.53$ & 12 & $2.67 \pm 0.47$ & 171 & $3.40 \pm 0.53$ & 52 & $3.97 \pm 0.64$ & 46 \\
\hline $\begin{array}{l}\text { Compare } \\
\text { d rank }\end{array}$ & Season & $d f$ & $x^{2}$ & $\begin{array}{l}p \text { - } \\
\text { value }\end{array}$ & Year & & $N$ & $Z$ & $U$ & $p$-value \\
\hline Male & $\begin{array}{l}\text { Wet vs } \\
\text { Dry }\end{array}$ & 1 & 0.882 & 0.348 & $1^{\text {st }}$ year vs & year & 30 & -2.72 & 25.0 & $0.006^{* *}$ \\
\hline Female & $\begin{array}{l}\text { Wet vs } \\
\text { Dry }\end{array}$ & 1 & 0.607 & 0.436 & $2^{\text {nd }}$ year vs & rd year & 13 & -1.50 & 10.5 & 0.133 \\
\hline $\begin{array}{l}\text { Both } \\
\text { sexes }\end{array}$ & $\begin{array}{l}\text { Wet vs } \\
\text { Dry }\end{array}$ & 1 & 2.202 & 0.138 & $1^{\text {st }}$ year vs & d year & 29 & -3.29 & 8.0 & $0.001 * *$ \\
\hline
\end{tabular}

